Strengthening Russia's Fiscal Framework

Charleen Gust and Daria Zakharova 
IMF Working Paper

European Department

\title{
Strengthening Russia's Fiscal Framework
}

\section{Prepared by Charleen Gust and Daria Zakharova*}

Authorized for distribution by Juha Kähkönen

March 2012

\section{This Working Paper should not be reported as representing the views of the IMF.} The views expressed in this Working Paper are those of the author(s) and do not necessarily represent those of the IMF or IMF policy. Working Papers describe research in progress by the author(s) and are published to elicit comments and to further debate.

\begin{abstract}
Though many aspects of Russia's fiscal policy framework are close to best practice on paper, actual practice in recent years has been moving away from best practice. In particular, the continued focus on the overall rather than the nonoil balance, and the regular use of supplemental budgets to spend windfall oil revenues contribute to procylicality of fiscal policy, risking costly boom-bust cycles. Against this background, this paper suggests several improvements to the framework for fiscal policy.
\end{abstract}

JEL Classification Numbers:E02, E62, H11, H50, H60

Keywords: fiscal policy, oil-producing countries, resource revenue management, accountability Author’s E-Mail Addresses: cadamgust@imf.org, dzakharova@imf.org

* We would like to thank Juha Kähkönen, Odd Per Brekk, Oksana Dynnikova, David Hofman, Daehaeng Kim, Kevin Fletcher, Prakash Kannan, Damiano Sandri, Mumtaz Hussain, Mauricio Villafuerte, Christine Richmond, and seminar participants at the Russian Ministry of Finance, Russian Ministry of Economy, and the Embassy of Finland/Bank of Finland Institute for Economies in Transition (BOFIT) for helpful comments and suggestions. 


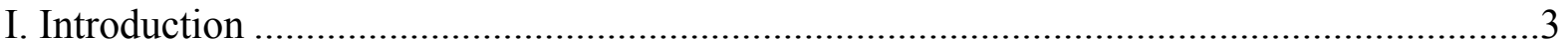

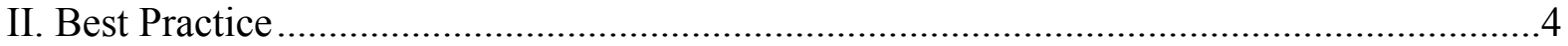

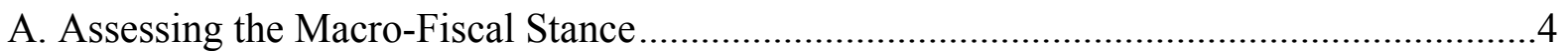

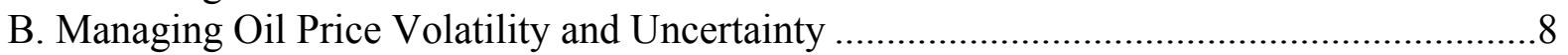

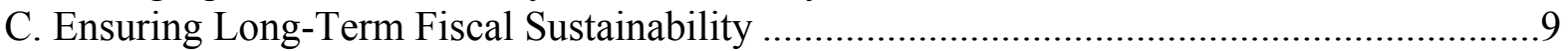

D. Complementary Fiscal Institutions …………………..................................................13

III. How Russia’s Current Fiscal Framework Compares to Best Practice..................................14

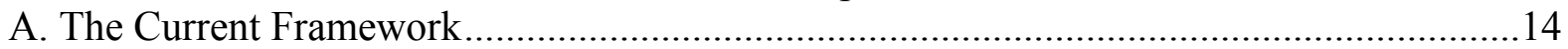

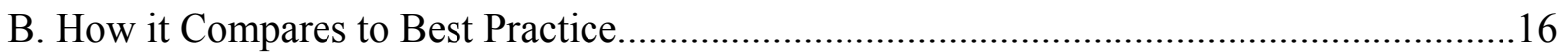

C. How it Compares to Other Countries...........................................................................

IV. Recommended Improvements to the Framework ............................................................18

Boxes

1. Hard Landing, Forceful Response, and Difficult Road Ahead............................................

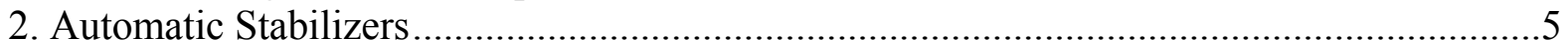

3. The Role of MTFFs in Managing Oil Revenue Uncertainty ..............................................

4. Long-Term Fiscal Risks in Russia ..............................................................................10

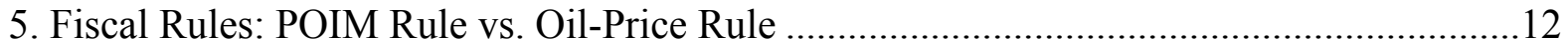

6. Alternative Specifications for Anchoring Long-Term Fiscal Policy in Russia ....................13

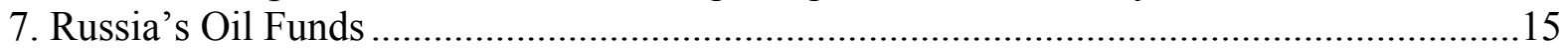

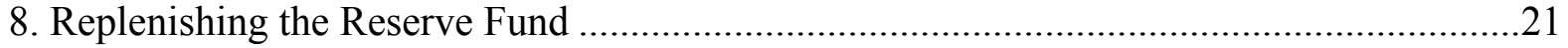

Figures

1. Traditional and Nonoil Fiscal Indicators, 2004-10 …......................................................

Tables

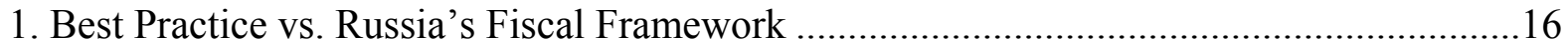

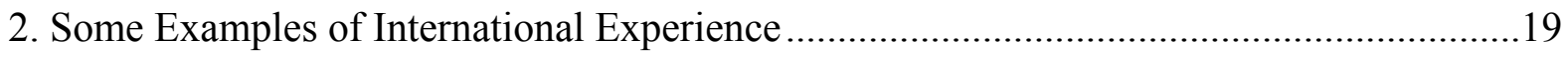

Appendix

A Permanent Oil Income Model (POIM) for Russia ............................................................23

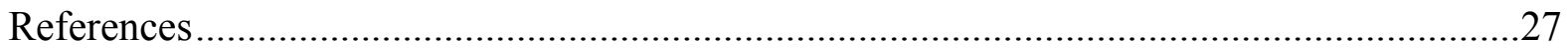




\section{INTRODUCTION}

As an oil-producing country, Russia faces important challenges to its fiscal management. Oil revenue tends to show high volatility and uncertainty compared with other fiscal revenues owing to the volatility of oil prices and the uncertainty associated with the size and exhaustibility of oil reserves. ${ }^{1}$ As a result, today's choices about investment in oil production capacity, the rate of extraction of oil, and the use of oil revenue have significant long-term economic implications. In addition, as oil revenue largely originates from abroad in the form of export receipts, it can have a significant impact on the real exchange rate and the country's competitiveness depending on how the inflows of foreign currency are managed.

Against this background, Russia has to consider a number of critical questions regarding fiscal policy and the management of oil revenues and wealth. These include: how to assess the fiscal stance to better inform policy decisions; how to shield public expenditures and the non-oil economy from the high volatility in (and uncertainty about) oil revenue; and how to address sustainability and intergenerational equity issues.

In recent years, Russia has not met these challenges as well as it could have. Fiscal policy has focused on the overall balance, rather than the nonoil balance. This has contributed to procyclical fiscal policies, which amplified the boom leading up to the crisis (Box 1). With ongoing pressures to spend windfall oil revenues, sustainability and intergenerational equity issues have taken a back seat.

A well-designed and consistently applied fiscal framework is needed to promote more effective policy implementation. Given the massive fiscal stimulus Russia undertook in response to the crisis, there is an urgent need to unwind the crisis-related measures and return to a sustainable fiscal position while oil prices are still high. A strengthened fiscal framework, alongside a more ambitious fiscal consolidation, would create a virtuous circle with reduced fiscal (and economic) vulnerabilities, increased credibility, and higher growth.

This paper suggests improvements to strengthen Russia's fiscal framework. It includes specific recommendations to strengthen Russia's fiscal framework to bring it in line with best practice, and is organized as follows. Section II discusses international best practice. Section III provides an overview of the current framework, and assesses how it compares to best practice. Finally, section IV presents recommendations to bring the framework in line with best practice.

\footnotetext{
${ }^{1}$ In Russia, natural gas is also abundant. For simplicity, this paper uses "oil" as shorthand for "oil and gas".
} 
Box 1. Hard Landing, Forceful Response, and Difficult Road Ahead*

Russia's story is one of quickly reversing fortunes. In the years leading up to the crisis, Russia enjoyed high but unsustainable growth fueled by ever increasing oil prices, strong capital inflows, and an increasingly expansionary policy mix. But as oil prices fell sharply and capital flows reversed abruptly during the crisis, Russia experienced the largest output contraction in the G-20. Poor economic diversification and lack of progress on structural reforms in the preceding years amplified the depth of the crisis. Nonetheless, the Russian authorities were able to mount a forceful response to the crisis owing to massive foreign exchange reserves built up during the boom years. Despite initial successes, however, the crisis response was not without flaws and was circumscribed by continued weak policy frameworks. In particular, a massive and poorly targeted fiscal stimulus knocked Russia's public finances off a sustainable path. The challenge ahead for fiscal policy is to put in place a credible, ambitious and growth-friendly strategy to successfully unwind the crisis-related policy support and return to a sustainable fiscal position while oil prices are still high.

* For a more detailed description and assessment of Russia's economic policy response to the 2008-09 crisis, see Hofman, Kozack, and Zakharova (2012, forthcoming).

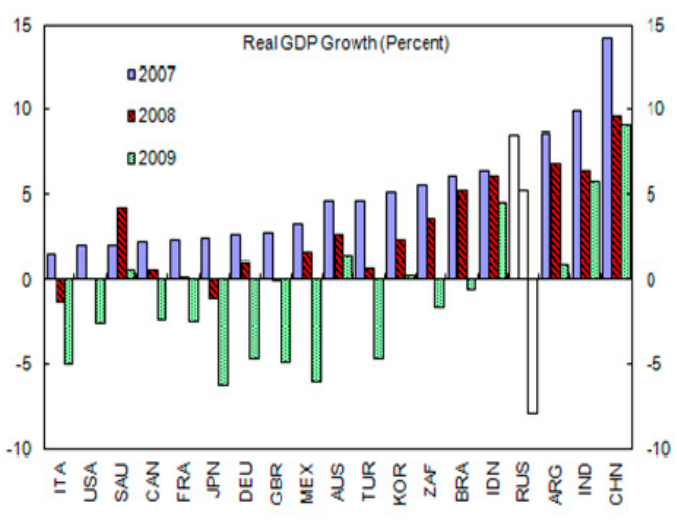

Sources: IMF, World Economic Outlook; and IMF staff calculations.

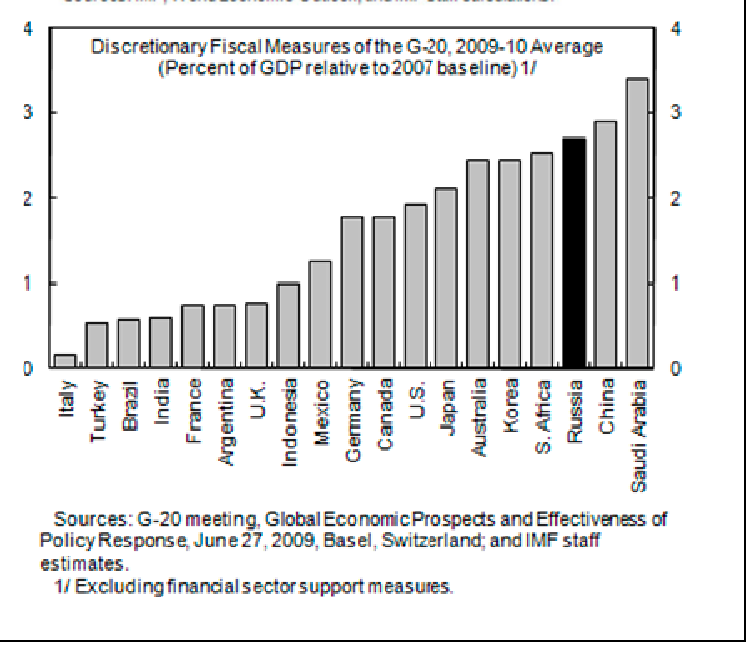

\section{Best Practice ${ }^{2}$}

\section{A. Assessing the Macro-Fiscal Stance}

The special nature of oil revenue complicates the evaluation of the macro-fiscal stance in oil producing countries (OPCs) such as Russia. Conventional fiscal indicators and tools, such as the overall and cyclically-adjusted primary balances (CAPBs) and debt sustainability analysis (DSA) are not sufficient to make a full assessment of the short-term fiscal stance or longer-term fiscal sustainability.

- $\quad$ Overall balance and CAPBs. CAPBs are generally more useful in assessing the direction of a country's fiscal policy than an overall balance, since they exclude net interest payments (which are not at the short-term discretion of policymakers) and the effect of automatic stabilizers (changes in government revenues and expenditures in response to a change in the cyclical position of the economy-see Box 2) on the overall balance. As

\footnotetext{
${ }^{2}$ This section draws on Medas and Zakharova (2009).
} 
such, CAPBs represent the discretionary part of fiscal policy. However, while an improvement in the CAPB would generally signal a discretionary fiscal tightening, such an improvement in an OPC could be associated with higher oil prices and higher oil revenues used to finance an increase in expenditure, thus masking a fiscal impulse. When output is above potential, such a fiscal impulse could lead to a pro-cyclical fiscal stance and economic overheating.

\section{Box 2. Automatic Stabilizers}

Automatic stabilizers are changes in government revenues and expenditures in response to a change in the cyclical position of the economy. In a recession, tax revenue from personal income and corporate profits usually fall faster than national income. Under a progressive income tax system, tax revenue tends to fall faster than household income as taxpayers move into lower tax brackets during a recession. Similarly, corporate profits usually fall faster than turnover, causing profit taxes to fall as a share of GDP. On the expenditure side, unemployment and welfare payments automatically increase as unemployment rises in a recession. Taken together, these factors result in an "automatic" worsening of the budget balance in a recession, helping to cushion economic activity.

- $\quad D S A$. Traditional DSAs mainly focus on the level of gross debt and achieving a sustainable primary fiscal balance - usually defined as the balance that maintains a constant debt-to-GDP ratio over the medium term. However, strategies aimed at stabilizing a positive net debt-to-GDP ratio will not generally be optimal or even consistent with fiscal sustainability in OPCs, since they could result in explosive debt dynamics when oil is exhausted, if the underlying fiscal deficit is large and nonoil growth is weak.

For these reasons, traditional fiscal indicators and tools for OPCs should be complemented by nonoil indicators and analysis of the long-term dynamics of the government's net wealth, including oil reserves in the ground. Nonoil fiscal indicators, such as the nonoil balance, should play a key role in guiding fiscal policy in OPCs since they can reveal the true underlying fiscal stance. The three most useful indicators for Russia are changes in real expenditures, the nonoil primary balance (NOPB), and the cyclically-adjusted nonoil primary balance (CANOPB). Long-term fiscal sustainability and oil wealth management issues are discussed in Section C.

- $\quad$ Changes in real expenditures. Though a traditional indicator, changes in real expenditures (i.e. nominal expenditures deflated by some price indicator such as the government consumption deflator, the GDP deflator, or the consumer price index) can show more clearly the evolution of government spending than simply looking at nominal expenditures alone, especially when inflation is high as in Russia.

- $\quad N O P B$. In addition to excluding net interest payments, this indicator excludes oil revenue and is therefore a better measure of the impact of discretionary fiscal policy on domestic demand than the overall balance. Ideally the NOPB should be expressed in percent of 
nonoil GDP, but in the absence of reliable estimates of nonoil GDP, as in Russia, a ratio to total GDP could be used. ${ }^{3}$

- $\quad C A N O P B$. This indicator excludes the effect of automatic stabilizers on the nonoil balance and therefore adjusts the measured fiscal stance for the impact of the business cycle. As with the NOPB, it should be expressed in percent of nonoil GDP. Norway is an example of a country that uses the CANOPB in percent of nonoil GDP as its fiscal anchor. However, for Russia, estimates of automatic stabilizers should be interpreted with some caution, since the elasticity estimates are unusually uncertain and estimation of potential GDP is complicated by the lack of reliable data on nonoil GDP and the large structural changes that have occurred in the economy over the past decade. For this reason, it is advisable to consider a range of indicators - including the NOPB and changes in real expenditures - when assessing the fiscal stance in Russia

Figure 1 below illustrates how a range of indicators can be helpful to assess fiscal policy in Russia. In particular, overall surpluses are not necessarily a sign of prudent fiscal policy as it is possible to run overall surpluses even when the nonoil balance is deteriorating.

- $\quad$ The first panel shows that fiscal surpluses are not necessarily a sign of prudent fiscal policies. As oil prices were increasing in 2004-08, traditional indicators such as the overall balance of the federal government (shown as bars) suggested that the fiscal position was deteriorating - as witnessed by the steady decline of the fiscal surplus. This deterioration is seen even more clearly if one looks at the nonoil overall balance of the federal government (shown as the broken line).

- $\quad$ These conclusions are reinforced by developments in the CANOPB. The second panel shows that the stance of fiscal policy has been procyclical during 2004-10, with the exceptions of 2004 and 2009 (global financial crisis), as the fiscal impulse-defined as the change in the CANOPB - was positive (negative) when the output gap was positive (negative). Fiscal policy was appropriately countercyclical during the crisis and in 2004.

- $\quad$ The third panel shows that developments in the cyclically-adjusted nonoil indicators (CANOPB) and indicators not adjusted for the cycle (NOPB) point to the same conclusion in regard to Russia's fiscal stance - both indicators show the deterioration of the fiscal position over 2005-09.

- $\quad$ Last, the fourth panel shows how real primary expenditures at the general government level have been increasing in step with oil prices, further illustrating how procyclical policies fuelled overheating in Russia prior to the crisis.

\footnotetext{
${ }^{3}$ This is because total GDP in OPCs with large oil sectors tends to fluctuate together with oil prices and production, causing the ratios of nonoil fiscal variables to vary significantly over time. Using total GDP to scale the nonoil balance may thus cloud the assessment of the fiscal position, if movements in the ratio are largely due to the changes in the denominator.
} 
Figure 1. Russia: Traditional and Nonoil Fiscal Indicators, 2004-10

A deterioration in fiscal position despite rising oil prices...

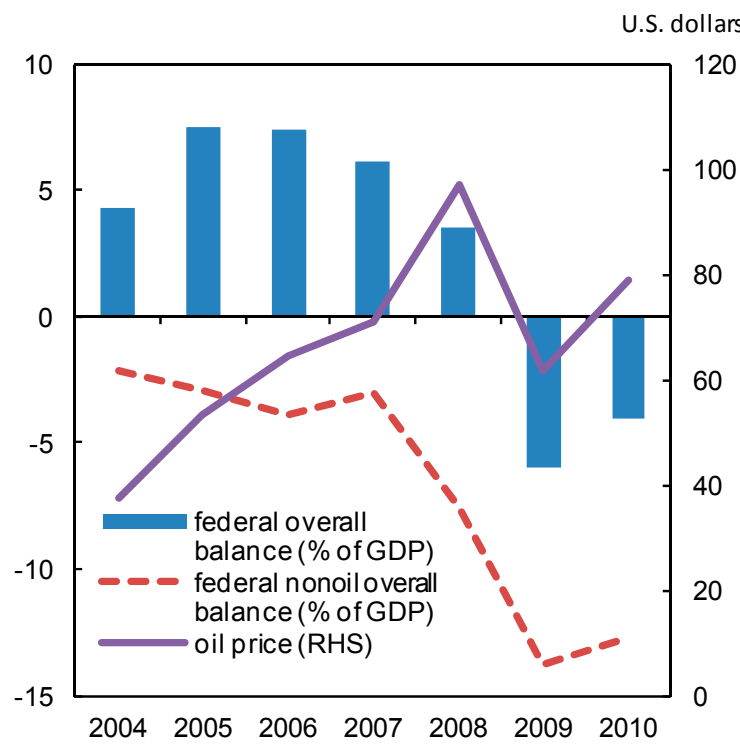

Nonoil and cyclically adjusted indicators tell the same story...

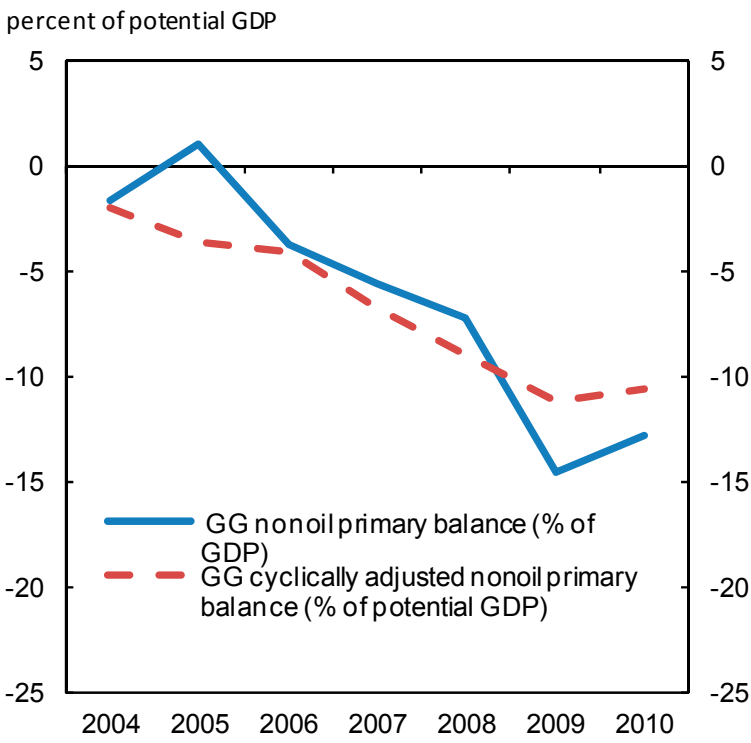

...led to procyclical policies.

percent of potential GDP

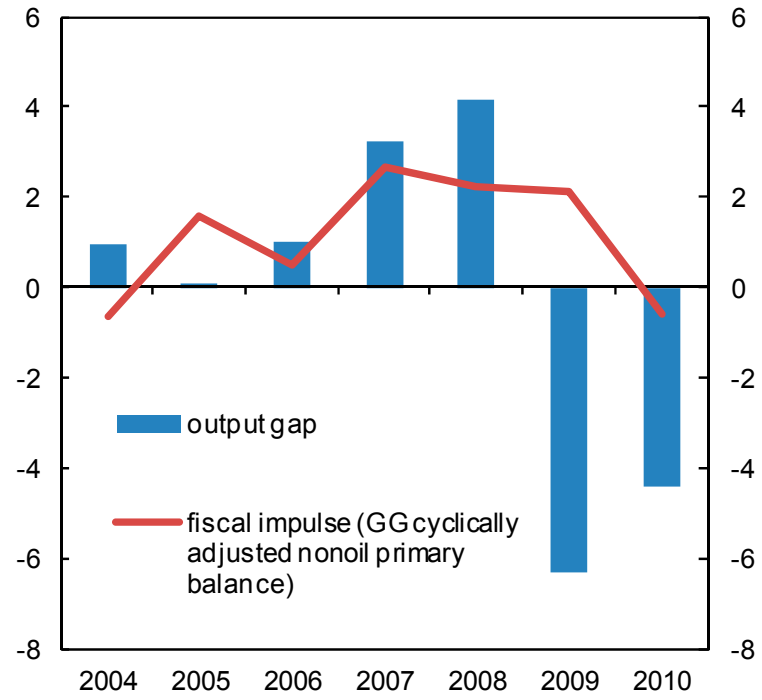

....as do real expenditures.

U.S. dollars

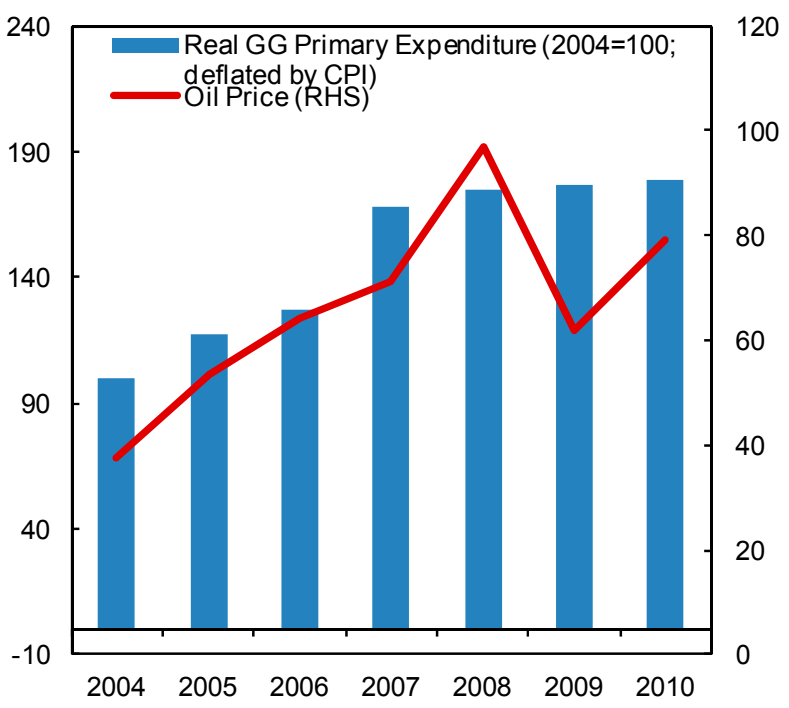

Source: WEO; and IMF staff estimates. 


\section{B. Managing Oil Price Volatility and Uncertainty}

Oil price volatility poses particular challenges for macroeconomic management in OPCs. ${ }^{4}$ Foreign exchange inflows associated with oil revenue often result in real exchange rate appreciation through nominal appreciation or higher inflation, depending on the exchange rate regime. Exchange rate appreciation may in turn undermine nonoil tradable goods sectors by reducing their competitiveness (Dutch disease), leaving the economy vulnerable to a sudden drop in oil prices. This loss of competitiveness, combined with higher inflation, could have serious negative consequences for the nonoil economy. These problems may be further aggravated by asset price bubbles which can form as a result of positive wealth effects of oil revenues, increasing financial sector vulnerability.

To mitigate these challenges, expenditure decisions should be de-linked from oil price volatility. This would require saving some of the oil revenue during an oil boom, and would enable the government to draw on savings to protect public services in a (temporary) downturn, contributing to a more stable macroeconomic environment. Spending decisions should be based on a longer-term perspective. In this context, a sustainable level of the nonoil balance could serve as a useful anchor for fiscal policy, for example as a sustainability benchmark embedded in a medium-term fiscal framework (MTFF — see Box 3 below). The framework should include an "escape clause" to allow temporary deviations of the nonoil balance from its sustainable level (e.g., Norway has an escape clause built into its fiscal rule so as to avoid ad hoc responses to unanticipated downturns in oil prices). ${ }^{5}$ In the case of Russia, best practice would be to: (i) anchor fiscal policy in a credible MTFF focused on the NOPB and based on conservative oil price assumptions, and include an escape clause to permit temporary deviations from the sustainable NOPB; and (ii) maintain a buffer for a rainy day by replenishing the oil funds (see Section IIIA).

\footnotetext{
${ }^{4}$ Though not discussed in this paper, the rate of oil extraction is another important factor that can also pose challenges for macroeconomic management.

${ }^{5}$ Sustainable levels of the nonoil balance are discussed in more detail in the sub-section that follows on ensuring fiscal sustainability.
} 


\section{Box 3. The Role of MTFFs in Managing Oil Revenue Uncertainty}

The need for a longer perspective and fiscal risk management in OPCs underscores the importance of MTFFs. An MTFF typically contains a statement of fiscal policy objectives and a set of integrated medium-term macroeconomic and fiscal targets and projections, which are consistent with the overall macroeconomic and development goals of the government.

An MTFF can help to link the annual budget to sustainability objectives and to improve risk analysis in OPCs by:

- Developing explicit strategies for managing external shocks (particularly oil price and exchange rate shocks) to facilitate a less disruptive adjustment process;

- $\quad$ Adequately planning for contingency reserves to smooth spending over the medium term in the face of shocks, including by conducting stress tests; and

- $\quad$ Ensuring that future generations benefit from the use of a nonrenewable resource by encouraging multi-year planning and focusing on delivering a stable and consistent level of public services.

\section{Ensuring Long-Term Fiscal Sustainability}

Assessing the sustainability of macro-fiscal policy in OPCs is both crucial and highly complex. The difficulties arise from having to assess the long-term consequences of current policies and from the high degree of uncertainty, particularly relating to the economic value of oil reserves. A central policy consideration is how conservative should countries be when managing oil wealth, given the uncertainty and long-term considerations.

There are several broad approaches to long-term management of oil wealth. While some liquidity-constrained governments with no (or very limited) access to financing sources or with relatively small oil reserves and revenue may choose to spend all current period oil revenue, best practice can be described by the approaches below. The desirability of each approach depends on a country's specific circumstances, and the role of country institutions also influences which approach would be best for any country. In the case of Russia, looming demographic challenges imply significant fiscal risks - stemming from potentially sizeable future pension and healthcare expenditures (see Box 4) — and hence, there is a need to preserve a share of today's oil wealth to ensure future generations can also benefit, particularly once oil reserves have been depleted. The rules below are listed from most conservative to least conservative. Best practice calls for a periodic reassessment of the long-term target implied by these rules, based on oil-price stress tests and developments in the oil markets, oil price futures, and probable reserves estimates. ${ }^{6}$ In the short run, the level of spending would also need to be consistent with maintaining macroeconomic stability, implying that the NOPB could be allowed to temporarily deviate from its sustainable level — for example to allow a temporary fiscal stimulus in an economic downturn - as long as the government has a clear and credible plan on how to return to a sustainable fiscal position over the medium term. The particular institutional

\footnotetext{
${ }^{6}$ This is done, for example, in Chile where an independent panel of experts (the "copper panel") meets annually to define the long-term copper price that determines the budget envelope for the following year. See Dabán (2011).
} 
set-up in a country also plays an important role in influencing which approach to long-term management of oil wealth is most applicable for that country.

\section{Box 4. Long-Term Fiscal Risks in Russia}

As many other countries, Russia faces long-term fiscal risks from future healthcare and pension spending, partly owing to population aging.

- Pensions. The potential costs of future public pension liabilities are estimated to be high:

$>$ Hauner (2008) estimates that, absent other reforms such as an increase in the retirement age, stabilizing the replacement rate for pensions at 30 percent (which is still 10 percentage points below the minimum in OECD countries), would require an increase in federal government transfers to the pension fund by more than 4 percent of GDP until approximately 2030, then declining to still 3 percent of GDP in 2050.

> Gurvich (2010) underscores the high costs of future pension liabilities, estimating that to keep the pension replacement rate at its 2010 level of 38 percent would require a substantial increase in the size of federal government transfers to the pension fund: in 2026 it will exceed 5 percent of GDP, in 2036 it will rise above 7 percent of GDP, and by the end of the period it will reach 10.6 percent of GDP. On average, the transfer will have to be increased by 1 percentage point of GDP every five years during 2010-50.

$>$ The Russian Ministry of Health has also produced a report on pension reform (see http://www.minzdravsoc.ru/docs/mzsr/insurance/6 for the Russian version) which concludes that pension reform is necessary to reduce the deficit of the pension fund and stabilize the volatility of the pension replacement rate

- $\quad$ Healthcare. IMF (2010) estimates that public healthcare spending could increase by between 0.7 and 1.6 percent of GDP between 2010 and 2030. About a quarter of this increase will come from aging, with the remainder stemming from excess cost growth (i.e. the growth in public health spending in excess of GDP growth after controlling for the effect of aging).

- "Bird-in-hand." A "bird-in-hand" rule is one where countries would save all oil revenue as financial assets, with only the yield from the accumulated financial assets spent. Norway broadly follows such an approach. The "bird in hand" rule is usually seen as the most conservative and tends to be restrictive, particularly in the early years of oil exploration when the accumulated financial wealth is low. For this reason, it is better suited for countries where there is a strong preference for transferring a substantial share of the oil wealth to future generations (e.g., due to aging of the population) or where there are sustainability concerns. ${ }^{7}$ In this regard, the "bird-in-hand" rule works well for countries that already have adequate public infrastructure in place and do not require large-scale government investments to boost productivity and growth potential. Thus, even though the rule appears to be well suited for Norway, it may not be optimal for emerging markets, such as Russia.

\footnotetext{
${ }^{7}$ The "bird-in-hand" rule also substantially reduces the impact of oil price movements in the annual budgets. The nonoil deficit is linked to the size of returns from the accumulated financial assets. However, the rule can introduce another kind of volatility to the budget, as the returns on the assets could have a high degree of volatility (depending on the investment strategy and size of the assets).
} 
- $\quad$ POIM. Countries may target a level of spending guided by the return on overall net government wealth - net financial assets plus oil wealth (this approach is also known as the Permanent Oil Income Model (POIM)). Under a POIM approach, governments consume a constant share of the net government wealth (e.g. as a percent of nonoil GDP — or in the case of Russia where nonoil GDP is not readily available, total GDP) every year to ensure a constant share for each generation. A standard POIM approach implies a stable nonoil deficit on average over time and could be attractive to countries that would like to keep the size of government constant in relation to the size of their economies. However, the rule also implies that wealthier future generations (assuming nonoil GDP grows over time) will receive a larger share of the oil wealth in real terms. This rule tends to be less restrictive in the early years of oil extraction than the "bird-inhand" rule, but becomes more restrictive over time, when accumulated financial wealth allows for higher consumption under the "bird-in-hand" rule. When governments have large social and infrastructure needs, as is the case in Russia, spending more of the net wealth than the return on financial wealth would likely be more appropriate and politically feasible.

- $\quad$ POIM-real criterion. Countries may also use a POIM-real criterion approach where the objective is to maintain the purchasing power of the wealth distributed each year, with government spending remaining constant in real terms (adjusted by a deflator). A POIMreal criterion rule implies a declining annuity over the years as a share of GDP, as long as real GDP is growing. As a result, the size of government declines in relation to the size of the economy, but the government continues to provide the same value of services in real terms over the years. This rule is less restrictive in the early years of oil exploration than the standard POIM approach, but becomes more conservative in the outer years. The POIM-real criterion rule could therefore be well suited to countries, like Russia, that prefer to frontload the spending of their oil wealth to invest in public goods that could boost future output. At the same time, these countries would need to be comfortable with a diminishing role of the public sector in the economy over time.

- $\quad$ DSA. A standard debt sustainability (DSA) approach could also be used. This approach (common in Fund-supported programs for non-oil producing countries) targets a primary balance that stabilizes public debt at a certain level, once oil runs out. The DSA is usually considered ill suited for resource-rich countries because it implies that the oil wealth is spent upfront, ignoring intergenerational equity aspects. Depending on how the oil wealth is used, such frontloaded spending could trigger inflation and excessive real exchange rate appreciation, undermining short-term macroeconomic stability and exacerbating the Dutch disease. Nevertheless, an argument can be made in favor of the upfront use of oil wealth, especially in developing countries where significant investments in physical and human capital are needed to improve long-term growth prospects. These considerations, however, should be carefully balanced against the strength of public financial management procedures in the country in question and with the need to address long-term fiscal risks, including from population aging. In the case of Russia, this approach may not be appropriate since, as noted above and in Box 3, 
long-term fiscal risks are not trivial, suggesting caution in relying on public debt to finance long-term government spending. Moreover, the experience of some advanced countries in the recent financial crisis also shows that public debt could increase to unsustainable levels almost overnight when countries are hit by large and unexpected shocks.

From the four rules considered above, the POIM or the POIM-real criterion rules would be most appropriate for Russia. These rules are most appropriate since: (i) they are sufficiently conservative to address the considerable fiscal risks facing Russia in the long run-including the potentially large fiscal costs of pension reform and the long-term spending pressures from rising healthcare costs; and (ii) a similar rule — stabilizing the nonoil deficit in percent of GDP — has already been incorporated into Russia's budget code, signaling the authorities' preference for the welfare criteria underlying the rule. Recently however, the authorities have indicated that they are exploring whether to replace the POIM-type nonoil deficit rule with an oil-price rule. We see either the POIM or POIM-real criterion rules as most appropriate for Russia, in line with IMF 2011 b (Box 5). A more conservative rule would also allow time to strengthen public financial management systems and to improve the quality of spending going forward. A comparison of the four rules discussed above with the current 2011-13 budget, however, suggests that current policies are inconsistent with all but the DSA approach, which we do not view as appropriate for Russia. ${ }^{8}$ On the positive side, the authorities' suspended long-term nonoil deficit target of 4.7 percent of GDP is broadly consistent with the POIM-real criterion rule, if reached by 2015 . This, however, would require a more ambitious fiscal consolidation than currently planned (Box 6) and it is possible to calibrate an adjustment back to a POIM spending path, for instance as has been done in Caracillo, Leigh and Villafuerte (2007).

\section{Box 5. Fiscal Rules: POIM Rule vs. Oil-Price Rule}

International experience suggests that a fiscal rule, backed by strong political support, can help to anchor fiscal policy and achieve balanced economic growth. Russia is currently considering whether to reinstate the long-term nonoil deficit target that was suspended during the global financial crisis or to replace it with an oil-price rule, where revenue above a certain oil price is saved in the oil funds. IMF staff continue to see the long-term nonoil deficit target as the best anchor for fiscal policy in Russia, as discussed in IMF $2011 \mathrm{~b}$. An oil-price rule can seem appealing because it is easy to communicate and could help to delink government expenditure and the economy from oil price volatility. However, it would still be a second-best alternative to the nonoil deficit rule since it does not necessarily preserve the wealth from oil for future generations as a nonoil balance target does. Moreover, to be an effective fiscal anchor, the oil-price rule must be supplemented with a ceiling on expenditure to avoid procyclical fiscal policy.

\footnotetext{
${ }^{8}$ The new 2012-14 medium-term budget is even less ambitious in the amount of fiscal consolidation delivered by the end of the budget period, though the nonoil deficit will be slightly lower in 2014 than the currently-budgeted 2013 level. Thus, the analysis that the current budget is inconsistent with all but the DSA approach still holds.
} 


\section{Box 6. Alternative Specifications for Anchoring Long-Term Fiscal Policy in Russia}

Based on oil price assumptions from the July 2011 WEO, our calculations suggest that the POIM approach would be consistent with a general government nonoil primary deficit of about 11/2 percent of GDP by 2015 (see text chart) and as such would imply a rather large consolidation in the medium-term, but would allow a higher level of consumption of oil wealth in the outer years (i.e. after the oil runs out) than under the POIM-real criterion rule.

In contrast, the POIM-real criterion rule would allow greater consumption of oil wealth up-front with a smaller (though still sizeable) fiscal consolidation in the medium-term to about $5 \frac{1}{2}$ percent of GDP by 2015 (see chart), but would mean a lower level of consumption of oil wealth in the outer years than under the POIM rule. Stress tests suggest that the results from both the POIM and POIM-real criterion rule are fairly robust to the impact of alternative assumptions. Nevertheless, a significant drop in long-term oil prices (compared to the current relatively optimistic forecast of US\$104/barrel) would require a stronger adjustment. For example, if long-term oil prices were to fall to US\$55/barrel—which oil futures price data imply has a 10 percent probability of happening - the sustainable NOPD would fall to about $3 \frac{3}{4}$ percent of GDP in 2015.

Further simulations of the POIMreal criteria model suggest that the

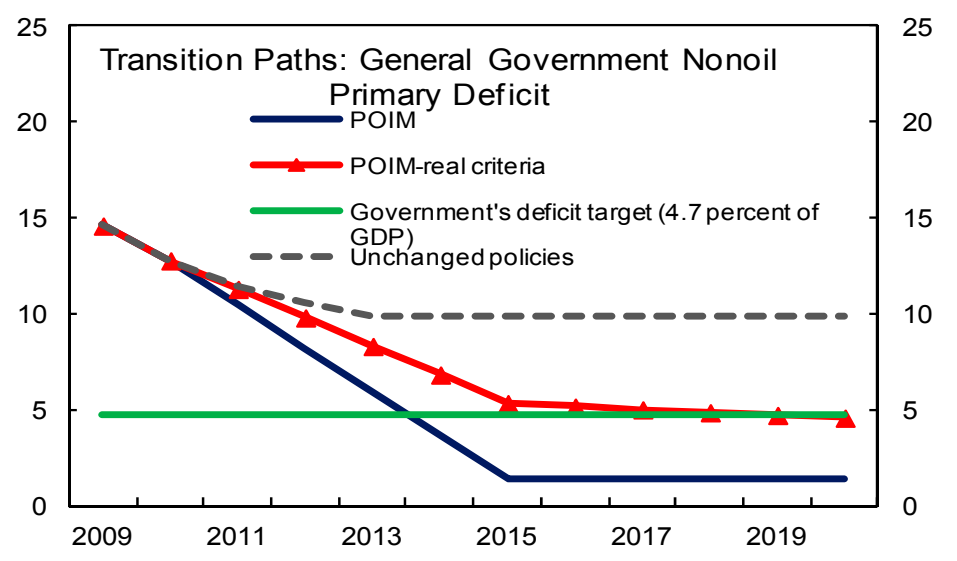

Source: IMF staff estimates. authorities' current deficit target of 4.7 percent of GDP (note that this target refers to the federal budget) would be sustainable at a long-term oil price of about US $\$ 82$ under a POIM-real criteria rule. Currently, oil futures data imply there is about a 40 percent probability that the oil price would fall to this level by 2013 - which suggests that the authorities' target is prudently conservative, given the inherent high volatility of oil prices. However, under either the standard POIM or the POIM-real criterion approach, a more ambitious fiscal consolidation is needed in order to achieve long-term sustainability.

\section{Complementary Fiscal Institutions}

Fiscal responsibility laws (FRLs) and independent fiscal agencies tasked with the monitoring and assessment of fiscal developments may be useful complements to the fiscal rules discussed above. FRLs are a subset of the wider set of budget-related laws that encompass all budget principles. They are defined as a limited-scope law that elaborates on the rules and procedures relating to three budget principles: accountability, transparency, and stability. ${ }^{9}$ Similarly, an independent fiscal agency or a fiscal council can help in the formulation and implementation of sound fiscal policies, and also play a monitoring and analytical role. The desirable form of such an agency (or a fiscal council) is country-specific and depends on the nature of the fiscal

\footnotetext{
${ }^{9}$ As in Lienert (2010).
} 
situation and on the country's political environment, including the constitutional setup, the legal tradition and policymaking customs.

International experience suggests that to be effective such agencies should include two essential components: (i) an explicit and transparent characterization of what the government views as a desirable (unbiased) fiscal policy and (ii) ways to enhance the (political or reputational) costs of deviations from unbiased policy. ${ }^{10}$ In addition, strong public financial management systems and a credible political commitment to sound overall macro-fiscal policies are necessary to ensure the effective use of oil resources in OPCs, regardless of the institutional set-up. ${ }^{11}$

An independent fiscal agency that conforms to best practice, both on paper and in practice, can complement the role played by existing institutions and enhance the effectiveness of fiscal rules. Such an agency - tasked with conducting impartial fiscal analysis and assessment of fiscal policy implementation - could help to increase transparency and accountability of fiscal policy, and raise the political cost of inappropriate policy. One role of a fiscal agency that would be particularly useful for Russia would be to provide an independent view on the oil price consistent with the fiscal rule (or vice versa). Such an independent determination of the appropriate oil price could help to provide consistency in the oil price used to guide both fiscal and monetary policy.

\section{How Russia’s Current Fiscal Framework Compares to Best Practice}

\section{A. The Current Framework}

Russia's legal fiscal framework goes in the right direction and includes the following elements.

- $\quad$ First, it has relied on the nonoil balance as a key fiscal indicator. The budget code includes a long-term nonoil deficit target of 4.7 percent of GDP, though the target was suspended in April 2009 (as a result of the global financial crisis) through end-2013.12

- Second, to manage macroeconomic volatility and uncertainty and to account for the longer-term consequences of spending decisions, Russia uses a medium-term fiscal framework, underpinned by rolling three-year budget plans, to set fiscal policies.

- $\quad$ Third, Russia maintains two oil funds (see Box 7 below), the Reserve Fund (which operates as a "rainy day" fund) and the National Wealth Fund (which is oriented towards long-run saving and creates a store of value for future generations).

\footnotetext{
${ }^{10}$ See Debrun, Hauner, and Kumar (2009).

${ }^{11}$ See Medas and Zakharova (2009) and Ossowski, Villafuerte, and Medas (2008).

${ }^{12}$ The target was suspended initially until January 1, 2013 and in September 2010, the suspension was extended until January 1, 2014.
} 
- $\quad$ And finally, to ensure long-term fiscal sustainability, the (currently suspended) nonoil deficit target incorporated into Russia's budget code is similar to a POIM rule in that it is aimed at supporting intergenerational equity objectives.

\section{Box 7. Russia's Oil Funds}

Russia established an oil fund in 2004, known as the Oil Stabilization Fund (OSF), reflecting the government's desire to shield itself from the volatility and uncertainty of oil prices, to accumulate reserves to pay off foreign debt, and to curb inflation. Over the period 2005-07, the OSF and other budget sources were deployed for early debt repayment of US\$47 billion in total, saving at least US $\$ 13$ billion in interest payments and smoothing budget expenses.

In 2008, the OSF was split into the Reserve Fund (RF) and the National Wealth Fund (NWF) and started to accumulate not only oil revenues but also natural gas revenues. As of March 1, 2009, the RF and NWF had reached US $\$ 136$ billion and US\$84 billion, respectively, in assets under management, as oil revenues in excess of the budgeted oil price were deposited in the oil funds. The objective of the RF is to finance federal budget deficits in periods of unfavorable world oil and gas prices, and the NWF's mission is to co-finance the voluntary pension savings of Russians and to maintain a balanced budget for the Pension Fund of Russia.

During 2009-10, the Russian government used, for the first time, a sizeable part of the assets of its oil funds to respond to the effects of the global financial crisis.
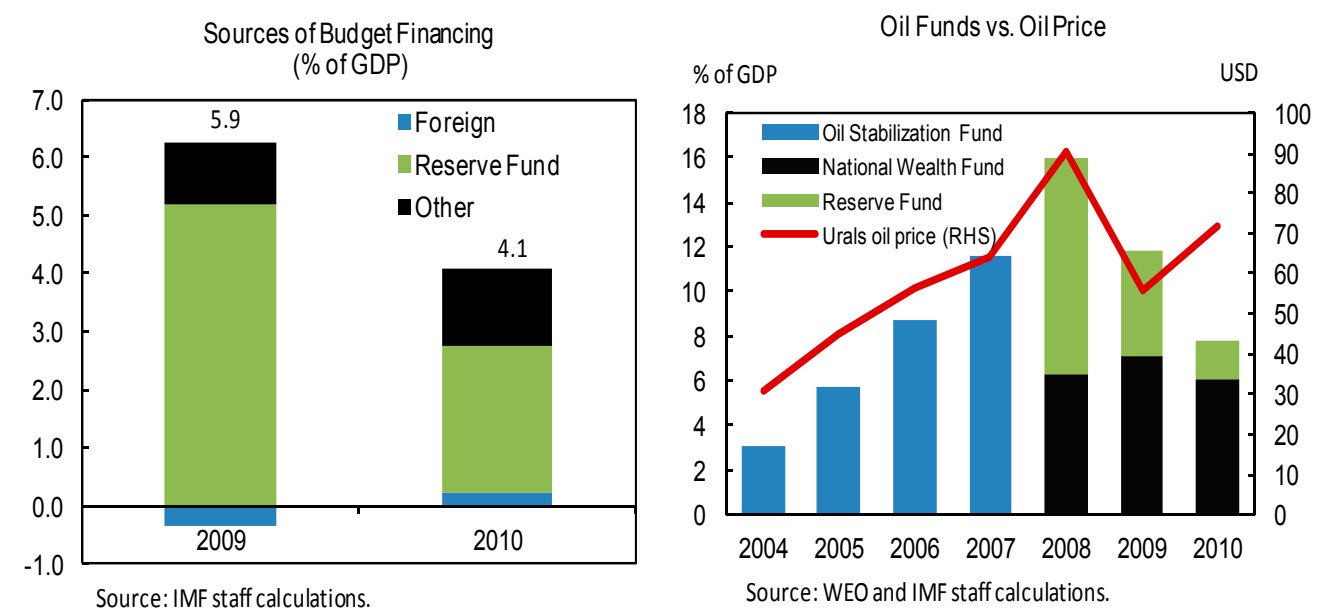

As of January 1, 2012, the RF had dwindled to only US $\$ 25$ billion, while the NWF stood at US $\$ 87$ billion. Before oil prices increased in the last few months of 2011, there appeared to be a danger that, unless replenished, the RF could run by the end of the year. However, higher-than-budgeted oil prices in 2011 will allow a transfer of $\$ 36$ billion to the RF in 2012.

Sources: Kazakevitch and Trishkina (2010) for description of the oil funds, data on oil fund balances from the Russian Ministry of Finance's website (www.minfin.ru), oil prices from the WEO database, and staff estimates. 


\section{B. How it Compares to Best Practice}

Table 1 below shows how Russia's fiscal framework compares to best practice. While on paper, many aspects of the framework are in line with best practice, actual practice in recent years has been moving away from best practice. This move away from best practice is due in part to the crisis, but even before the crisis, persistent spending pressures acted to weaken the application of the legal framework.

Table 1: Best Practice vs. Russia's Fiscal Framework

\begin{tabular}{|c|c|c|c|}
\hline & Best practice & Russia legal framework & Russia actual practice \\
\hline $\begin{array}{l}\text { Assessing the macro- } \\
\text { fiscal stance }\end{array}$ & $\begin{array}{l}\text { Use of nonoil indicators such } \\
\text { as (cyclically-adjusted) } \\
\text { nonoil primary balance as } \\
\text { key indicator }\end{array}$ & $\begin{array}{l}\text { The nonoil balance is } \\
\text { specified as the fiscal } \\
\text { anchor in the budget code } \\
\text { and is published in the } \\
\text { annual budget document }\end{array}$ & $\begin{array}{l}\text { The nonoil balance was } \\
\text { used as the main fiscal } \\
\text { indicator prior to the } \\
\text { crisis, but the focus has } \\
\text { since shifted to the } \\
\text { overall balance as fiscal } \\
\text { deficits emerged in the } \\
\text { aftermath of the crisis }\end{array}$ \\
\hline $\begin{array}{l}\text { Managing } \\
\text { macroeconomic volatility } \\
\text { and uncertainty }\end{array}$ & \begin{tabular}{|l|} 
Delink expenditure \\
decisions from oil revenue \\
volatility by anchoring fiscal \\
policy in a credible medium- \\
term fiscal framework \\
focused on NOPB (or \\
CANOPB) and maintaining \\
buffers to ameliorate \\
external shocks (e.g. oil \\
funds as "rainy day" funds)
\end{tabular} & $\begin{array}{l}\text { MTFF exists, underpinned } \\
\text { by rolling three-year budget } \\
\text { plans. Russia mantains two } \\
\text { oil funds: the Reserve Fund } \\
\text { (which serves as a "rainy } \\
\text { day" fund) and the National } \\
\text { Wealth Fund (which is } \\
\text { focused on long-term } \\
\text { intergenerational equity) }\end{array}$ & $\begin{array}{l}\text { Excessive use of } \\
\text { supplementary budgets } \\
\text { undermines the MTFF. } \\
\text { The Reserve Fund has } \\
\text { served Russia well as a } \\
\text { "rainy day" fund, but it is } \\
\text { now nearly depleted. }\end{array}$ \\
\hline $\begin{array}{l}\text { Ensuring long-term fiscal } \\
\text { sustainability }\end{array}$ & $\begin{array}{l}\text { For countries that do not } \\
\text { have very long-lasting oil } \\
\text { reserves (like Russia), } \\
\text { implement fiscal rule based } \\
\text { on POIM approach to } \\
\text { support intergenerational } \\
\text { equity and preserve fiscal } \\
\text { sustainability }\end{array}$ & $\begin{array}{l}\text { Russia's budget code does } \\
\text { have a long-term nonoil } \\
\text { deficit target that is broadly } \\
\text { in line with a POIM } \\
\text { approach }\end{array}$ & $\begin{array}{l}\text { Target was suspended } \\
\text { during the crisis }\end{array}$ \\
\hline $\begin{array}{l}\text { Complementary fiscal } \\
\text { institutions }\end{array}$ & $\begin{array}{l}\text { Independent fiscal agency } \\
\text { can help in formulation and } \\
\text { implementation of sound } \\
\text { fiscal policies }\end{array}$ & $\begin{array}{l}\text { Does not have independent } \\
\text { fiscal agency }\end{array}$ & $\begin{array}{l}\text { Does not have } \\
\text { independent fiscal } \\
\text { agency }\end{array}$ \\
\hline
\end{tabular}


- $\quad$ Assessing the macro-fiscal stance. As recommended by best practice, Russia's budget code includes the use of the nonoil balance as a long-term target for fiscal policy and the nonoil balance was indeed used as the main fiscal indicator prior to the global financial crisis. However, the focus of fiscal policy has since shifted to the overall balance as fiscal deficits emerged in the aftermath of the crisis and the nonoil deficit target has been suspended through 2013. The chart at right shows that the current

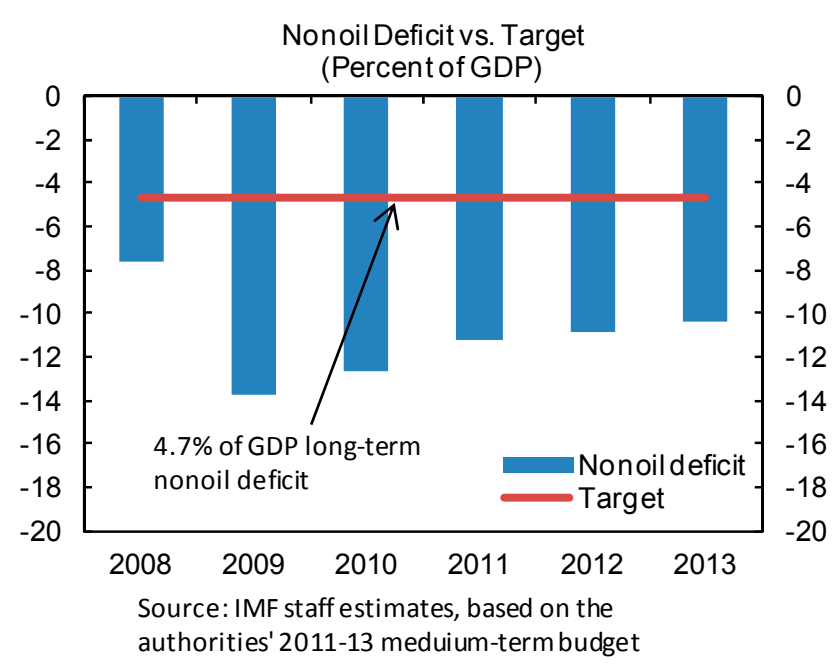
medium-term consolidation plans through 2013 leave the nonoil deficit well in excess of the 4.7 percent of GDP target.

- $\quad$ Managing macroeconomic volatility and uncertainty. In line with best practice, Russia has a medium-term fiscal framework to help delink expenditure decisions from short-term variations in oil revenue. However, supplementary budgets have been passed in every year since the 1998 crisis, reflecting persistent spending pressures. Since 2004, with the exception of the recent crisis, the changes implied by the supplementary budgets have invariably increased the procyclicality of fiscal policy.

Oil Price, U.S. Dollars per Barrel

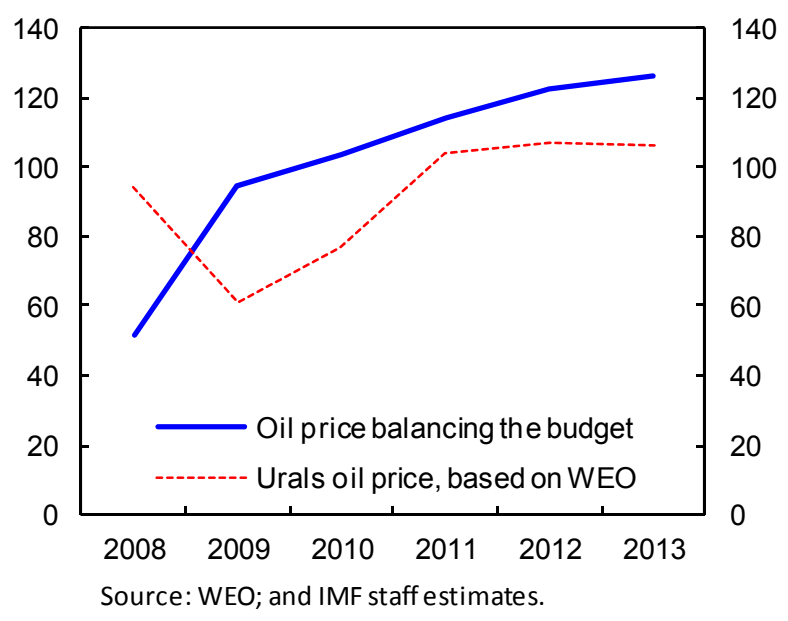

Furthermore, when the crisis was abating in 2010 and oil prices were recovering, the authorities continued to draw on the Reserve Fund to finance the overall deficit rather than embarking on a removal of crisis-related stimulus. As such, Russia's fiscal finances are now more vulnerable than in the pre-crisis period - the oil price that balances the budget is now much higher than pre-crisis (see chart at right) and with the Reserve Fund now all but exhausted, Russia will have to meet its financing needs in the market over the next few years. ${ }^{13}$

- $\quad$ Ensuring long-term fiscal sustainability. Again in line with best practice, Russia has a long-term nonoil deficit target that is broadly in line with a POIM approach. However,

\footnotetext{
${ }^{13}$ This is especially true if no further consolidation is taken after 2013.
} 
this target was suspended during the crisis which has left Russia without a medium-term anchor for fiscal policy.

- $\quad$ Complementary fiscal institutions. Russia does not have an independent fiscal agency, as would be best practice. The Audit Chamber is charged with evaluating the government's performance against its fiscal targets as part of the evaluation of the Federal Budget execution, but there is no requirement that the government acts on the Audit Chamber's evaluation.

\section{How it Compares to Other Countries}

International experience confirms that strong frameworks are not enough to ensure successstrong implementation of the framework is essential. Table 2 below shows Norway, as an example of a success story with its fiscal framework, and Nigeria, as a cautionary tale. Norway is aligned with best practice for many aspects of its framework. Though it does not have a MTFF, or an independent fiscal agency, there is strong commitment to the implementation of the "4 percent rule". Russia's legal fiscal policy framework is on par with that in Norway, but as discussed in Section B above, the Russian framework has been undermined by inconsistent implementation. Nigeria is an example of a country that has seen its policy framework undermined recently (since 2010) by weak implementation. Its oil fund (the Excess Crude Account) had been all but depleted in 2010, prompting the specter of a ratings downgrade. ${ }^{14}$ With Russia's weak implementation of its framework and the Reserve Fund at low levels, Nigeria's experience is illuminating.

\section{RECOMMENDED IMPROVEMENTS TO THE FRAMEWORK}

Drawing on the discussion above on the various elements of best practice for fiscal frameworks in oil-producing countries, the following improvements to Russia's fiscal framework are recommended:

- $\quad$ Assessing the fiscal stance: Russia should focus on the nonoil balance as a fiscal anchor. Consistent use of the nonoil deficit as the key indicator of fiscal policy would provide an anchor for fiscal policy, independent of volatile commodity prices. As reliable estimates of nonoil GDP for Russia become available and estimates of potential output growth are refined, Russia should use the CANOPB definition to guide fiscal policy.

\footnotetext{
${ }^{14}$ Fitch Ratings revised the outlook on Nigeria's rating from stable to negative in October 2010. In October 2011, the outlook was revised back to stable, in part due to an improved fiscal stance that resulted in an increase in the Excess Crude Account balance.
} 
Table 2: Some Examples of International Experience

\begin{tabular}{|c|c|c|c|}
\hline & Best practice & Norway & Nigeria \\
\hline $\begin{array}{l}\text { Assessing the macro- } \\
\text { fiscal stance }\end{array}$ & $\begin{array}{l}\text { Use of nonoil indicators } \\
\text { such as (cyclically } \\
\text { adjusted) nonoil primary } \\
\text { balance as key indicator }\end{array}$ & $\begin{array}{l}\text { Nonoil structural central } \\
\text { government deficit is key } \\
\text { indicator for fiscal policy. } \\
\text { It is enshrined in law and } \\
\text { consistently implemented. }\end{array}$ & $\begin{array}{l}\text { Does not use nonoil } \\
\text { indicators. Uses oil price- } \\
\text { based fiscal rule, which is } \\
\text { part of the Fiscal } \\
\text { Responsibility Act. Since } \\
\text { specification of the rule is } \\
\text { not enshrined in law, the } \\
\text { rule has not been } \\
\text { consistently implemented } \\
\text { in recent years. }\end{array}$ \\
\hline $\begin{array}{l}\text { Managing } \\
\text { macroeconomic volatility } \\
\text { and uncertainty }\end{array}$ & $\begin{array}{l}\text { Delink expenditure } \\
\text { decisions from oil revenue } \\
\text { volatility by anchoring } \\
\text { fiscal policy in credible } \\
\text { medium-term fiscal } \\
\text { framework focused on } \\
\text { NOPB (or CANOPB) and } \\
\text { maintaining buffers to } \\
\text { ameliorate external } \\
\text { shocks (e.g. oil funds as } \\
\text { "rainy day funds") }\end{array}$ & $\begin{array}{l}\text { No multi-year approach to } \\
\text { budgetary planning. } \\
\text { Norway maintains the } \\
\text { Government Pension } \\
\text { Fund Global (GPFG), } \\
\text { whose purpose is to } \\
\text { support long-term } \\
\text { management of petroleum } \\
\text { revenues. Proceeds from } \\
\text { the fund are used to } \\
\text { finance the nonoil deficit. }\end{array}$ & $\begin{array}{l}\text { Uses Medium-Term } \\
\text { Expenditure Framework. } \\
\text { Nigeria maintains the } \\
\text { Excess Crude Account } \\
\text { but it has been nearly } \\
\text { depleted as a result of } \\
\text { weak implementation of } \\
\text { the fiscal rule in recent } \\
\text { years. }\end{array}$ \\
\hline $\begin{array}{l}\text { Ensuring long-term fiscal } \\
\text { sustainability }\end{array}$ & $\begin{array}{l}\text { Implement fiscal rule } \\
\text { based on POIM approach } \\
\text { to support } \\
\text { intergenerational equity } \\
\text { and preserve fiscal } \\
\text { sustainability }\end{array}$ & $\begin{array}{l}\text { Nonoil deficit target is } \\
\text { broadly in line with a "bird- } \\
\text { in-hand" approach ("4 } \\
\text { percent rule" stipulates } \\
\text { that the nonoil structural } \\
\text { deficit should average, } \\
\text { over time, } 4 \text { percent of the } \\
\text { value of the GPFG). }\end{array}$ & $\begin{array}{l}\text { Fiscal rule based on oil- } \\
\text { price rule, not POIM rule. }\end{array}$ \\
\hline $\begin{array}{l}\text { Complementary fiscal } \\
\text { institutions }\end{array}$ & $\begin{array}{l}\text { Independent fiscal agency } \\
\text { can help in formulation } \\
\text { and implementation of } \\
\text { sound fiscal policies }\end{array}$ & $\begin{array}{l}\text { Does not have } \\
\text { independent fiscal agency }\end{array}$ & $\begin{array}{l}\text { Does not have } \\
\text { independent fiscal agency }\end{array}$ \\
\hline
\end{tabular}

Source: IMF (2011a) and OECD (2010). 
- $\quad$ Ensuring long-term fiscal sustainability: Russia should use a POIM rule. The analysis in Section IIIC suggests that the authorities' current nonoil deficit target of 4.7 percent of GDP could serve as a sustainable long-term fiscal anchor for Russia. Achieving this target by 2015 and maintaining the nonoil deficit at a sustainable level thereafter would be broadly in line with the POIM-real criterion approach. ${ }^{15}$ Accordingly, the target should be reinstated and the government should articulate an ambitious and credible fiscal consolidation plan to reach the target by 2015 .

- $\quad$ Managing macroeconomic volatility and uncertainty: Russia should avoid excessive use of supplemental budgets, use conservative oil price assumptions in the budget, and replenish the Reserve Fund. Specifically:

Russia should make a decisive break with its past practice of excessive use of supplemental budgets - this practice undermines the credibility and usefulness of the medium-term fiscal framework and can contribute to the procyclicality of fiscal policy.

$>\quad$ It should also use conservative oil prices in the budget, as was done until 2010, and introduce an escape clause into Russia's fiscal rule to allow for temporary deviations from the medium-term deficit target.

Last, the Reserve Fund should be replenished in order to allow it to continue to play its helpful shock-absorbing role for the Russian economy. As such, the authorities' plans to use some of the oil revenues in 2011 to replenish the Reserve Fund are welcome. Replenishing the Reserve Fund would reduce nearterm vulnerabilities as Russia would not need to rely on potentially fickle external funding sources to finance the current projected overall budget deficits. The analysis in Box 8 suggests that the authorities' current benchmark of keeping 10 percent of GDP in the Reserve Fund to hedge the financing of the budget against a sudden drop in oil prices is broadly adequate, given Russia's high nonoil deficit. But the difficulties of reaching this target should not be underestimated - even with prudent fiscal policies and the high oil prices assumed in the WEO, it would only be possible to reach this level by 2016 . The good news is that as Russia's fiscal framework is strengthened and fiscal vulnerabilities are reduced, there would be less need to hold money in the Reserve Fund to insure against downturns. Any "excess" holdings in the Reserve Fund could then be transferred into the National Wealth Fund to fund long-term fiscal liabilities, which would further reduce Russia's fiscal vulnerabilities.

\footnotetext{
15 The POIM-real criteria approach suggests that a continued very gradual fiscal consolidation would be required beyond 2015 (e.g., to about 2 percent of GDP by 2049, when oil runs out). See Appendix for further detail.
} 


\section{Box 8. Replenishing the Reserve Fund}

As noted in Box 7, the Reserve Fund played an important role in cushioning Russia from the impact of the global financial crisis.

However, unless it is replenished, the Reserve Fund could be exhausted in 2011. How much should be kept in the Reserve Fund in order to allow it to play its shock-absorbing role? One way to answer this question is to look at futures prices for oil and the probabilities of observing these prices. Using West Texas Intermediate (WTI) crude prices less a constant spread as a proxy for Urals oil prices, it is possible to construct a fan chart showing the probability of observing any particular future oil price. This fan chart is based on the historical mean and standard error of the data and the top and bottom of the ranges correspond to the 95 percent confidence interval. That is, with 95 percent confidence, we would expect to see oil prices by mid-2014 somewhere between US\$37/barrel and US\$207/barrel.

Taking a modified value-at-risk approach, we have estimated the gross financing need of the federal government using two tail risk scenarios where oil prices drop to the bottom of the 90 percent confidence interval (i.e. oil prices of US\$70 in 2011 and US\$61 in 2012) and the 95 percent confidence interval (i.e. oil prices of US\$60 in 2011 and US\$48 in 2012). Tail risk scenarios are used since the Reserve Fund is meant to be used as a rainy day fund and used in case of abrupt drops in oil prices, not as an everyday financing fund. Assuming the Reserve Fund should be able to cover about 18 months worth of gross financing needs in the face of an adverse event (which may be on the conservative side considering that Russia drew on its Reserve Fund to finance two years worth of fiscal deficits given adverse market conditions in the aftermath of the global financial crisis), our scenarios suggest that somewhere between 9 and 12 percent of GDP should be kept in the Reserve Fund. Against this backdrop, the authorities' target of keeping 10 percent of GDP in the Reserve Fund thus appears appropriate.

In terms of how to replenish the Reserve Fund, Russia should undertake a more ambitious, credible, and growthfriendly fiscal consolidation than what is contained in the 2011-13 budget. Budget scenario simulations which assume that the Reserve Fund is replenished to 2.7 percent of GDP in 2011 as planned by the authorities, and that a front-loaded consolidation is undertaken in order to reach the 4.7 percent of GDP nonoil deficit target by 2015 and keep the deficit at a sustainable level thereafter, suggest that it would be possible to have about 10 percent of GDP in the Reserve Fund by 2016. This level would allow the Reserve Fund to cover about 18 months of gross financing needs starting in 2016 under the tail risk scenarios discussed above. However, under unchanged policies (i.e. fiscal consolidation as in the 2011-13 budget), the Reserve Fund would stand at 3.0 percent of GDP by 2015 . Were the Reserve Fund to be drawn down to zero by end-2011 to finance the deficit under the baseline scenario, it would

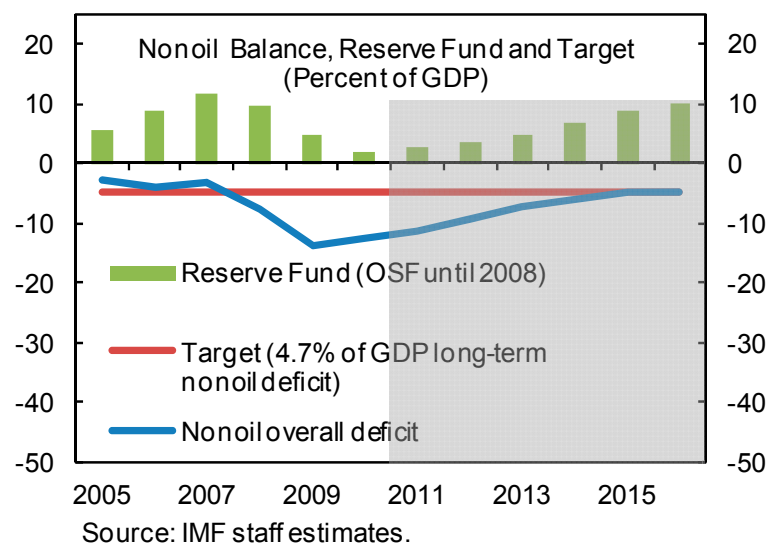
only have 0.9 percent of GDP in it by 2015 . 
- $\quad$ Complementary fiscal institutions: Russia should create an independent fiscal agency. Currently, there is no independent agency responsible for producing or evaluating the macroeconomic and fiscal projections in the budget, or evaluating the government's proposed fiscal policies. An independent fiscal agency should be established to provide the government with alternative macroeconomic and fiscal forecasts, analysis of fiscal policy under various scenarios, and independent assessments of compliance with the fiscal rule. This agency could be established either outside or within the Ministry of Finance. However, good rules and fiscal agencies cannot be a substitute for fiscal discipline as rules can be abandoned or circumvented, underscoring the need for political support for such arrangements.

- $\quad$ Other complementary reforms. An important complementary reform planned by the authorities is to prepare a comprehensive accounting of tax expenditures and make this part of the annual budget documents. This would increase transparency and provide a better basis for prioritization for use of budget resources. The increased transparency could also build public support for rationalization of tax incentives. Better assessment, disclosure and management of fiscal risks - for instance the risks stemming from contingent liabilities, such as the deposit insurance scheme and risks associated with government stakes in non-financial enterprises - are also needed. The authorities' work to date to develop a methodology for assessing the sustainability of borrowing of state-controlled enterprises and to introduce limits on the size and profile of external borrowing by these enterprises are positive steps in this regard. 


\section{Appendix: A Permanent Oil Income Model (POIM) for Russia}

In recent years, the POIM and its alternative specifications have become standard tools for assessing long-term fiscal policy in resource-rich countries. Operational aspects of the basic model are discussed in Barnett and Ossowski (2002) and policy implications, including the pros and cons of the approach, are discussed in Sachs (2007). Over the past few years, the approach (with various modifications) has been applied by IMF teams (e.g. IMF 2007a, IMF 2007b, and IMF 2007c), the World Bank (2010), and external experts. This appendix provides more background on the assumptions used and results obtained for Russia from similar approaches based on POIM and standard debt sustainability analysis.

Table 1 lists the assumptions underpinning the illustrative numerical simulations that apply the four approaches discussed in Section IIC above to Russia, whereas Figure 1 and Table 2 summarize the results. 2010 is assumed as a starting year for the simulations, based on an estimate of the general government's nonoil primary deficit and initial financial wealth. The results from the four approaches are fairly robust to the impact of alternative parameter assumptions, such as oil prices and reserves.

Table 1. Russia: Permanent Oil Income Model Assumptions

$\begin{array}{lr}\text { Parameters } & -4 \\ \text { Net financial assets (NFA; percent of GDP) 2010 1/ } & 4 \\ \text { Real return on assets (percent) } & 3 \\ \text { Long-term GDP growth rate (percent) } & 101 \\ \text { Long-term Ural's oil price (U.S. dollars per barrel; based on WEO prices) } & 264 \\ \text { Long-term gas price (per 1000 cubic meters, WEO) } & \\ \text { Calculations } & 152 \\ \text { Oil sector } & 38 \\ \text { Proven/unproven reserves (Billions of barrels) 2/ } & 3501 \\ \text { Years until depletion } & 44380 \\ \text { Present value 2008 of future oil cash flow accruing to government (Billions of U.S. dollars) } & 80 \\ \text { Gas sector } & 477 \\ \text { Proven reserves (Billions of cubic meters) 3/ } & \\ \text { Years until depletion } & 3974 \\ \text { Present value 2008 of future gas cash flows accruing to government (Billions of U.S. dollars) } & -67 \\ \text { Total } & 264 \\ \text { Energy wealth (Billions of U.S. dollars) } & \\ \text { NFA (Billions of U.S. dollars) } & \\ \text { Total net wealth (NFA plus energy; percent of GDP) } & \end{array}$

Source: IMF staff calculations.

1/ Reserve and National Welfare oil funds net of public debt.

2/ Estimated based on proven oil reserves: 74.2 billions of barrels in 2009

(BP Statistical Review of World Energy, June 2010), and undiscovered reserves: 77.4 billions of barrels in 2000 (The U.S. Geological Survey, 2000).

3/ BP Statistical Review of World Energy, June 2010. 
"Bird-in-hand". The "bird-in-hand" rule requires the steepest adjustment in the first few years to achieve a sustainable level of consumption consistent with the rule. The model implies a sharp adjustment in the general government nonoil primary deficit from 12.8 percent of GDP in 2010 to about $1 / 2$ percent of GDP by 2015 . However, as government financial wealth is gradually accumulated and the real return on this wealth increases, the rule allows for a gradual increase in government consumption to some 3.7 percent of GDP in 2049, when oil reserves are depleted. Over time, as the country runs out of oil and the accumulation of the government financial wealth slows, the sustainable nonoil deficit begins to decline as a share of growing GDP. In the outer years (not shown on the chart), as the economy continues to grow, the level of the sustainable nonoil primary deficit converges to zero.

POIM. A standard POIM approach that stabilizes the nonoil balance in percent of GDP implies a somewhat less restrictive spending profile in the early and outer years than the "bird-in-hand" rule. The nonoil primary balance is stabilized in the steady state at about $1 \frac{1}{2}$ percent of GDP from 2015 on.

POIM-real criteria. A POIM approach based on real criteria allows for a higher consumption in the early years than either the "bird-in-hand" or the standard POIM approach. In the medium term, the nonoil primary deficit declines from 12.8 percent of GDP in 2010 to about $5 \frac{1}{2}$ percent of GDP by 2015 , then gradually declines to about 2 percent of GDP by 2049 when oil runs out, and continues to slowly decline thereafter. The average implied nonoil deficit during 2010-49 is about 41/4 percent of GDP. However, in the very long run, similar to the "bird-in-hand" scenario, as net government wealth plateaus in real terms against the backdrop of growing GDP, the sustainable nonoil deficit converges to zero as a share of GDP.

DSA. This scenario assumes that the public-debt-to-GDP ratio is stabilized at 30 percent when the country runs out of oil in $2049 .{ }^{16}$ Under the standard assumption of an interestgrowth differential of 1 percent ${ }^{17}$ this implies that Russia would need to run a primary surplus of 0.3 percent of GDP from 2051. As oil and gas run out, the nonoil primary balance should be stabilized at this level. The illustrative simulation calibrates the medium-term adjustment in the NOPB to reach the targeted level of debt by 2049, whereas the longer-term gradual adjustment is calibrated to achieve a smooth transition to the primary surplus of 0.3 percent of GDP by 2049. This scenario implies an initial adjustment in the NOPB of the general

\footnotetext{
${ }^{16}$ Recent studies have identified a threshold of 40 percent of public debt to GDP (compared to end-2010 ratio of some10 percent of GDP in Russia) to mark the limit where the risk of debt distress significantly increases (IMF (2003)). The debt-to-GDP benchmark of 30 percent was chosen conservatively, in light of serious long-term fiscal risks facing Russia.

${ }^{17}$ For further discussion, see paragraph 41 in IMF (2009b).
} 
government from the current deficit of 12.8 percent of GDP to about 9 percent of GDP by 2015 and a gradual convergence to the NOPD of 0.3 percent of GDP by 2049 .

Table 2. Russian Federation: General Government Balances and Financial Wealth

\begin{tabular}{lrrrrrr}
\hline & 2010 & 2015 & $2010-15$ & 2049 & $2010-49$ & 2110 \\
\hline $\begin{array}{l}\text { Nonoil primary balance } \\
\text { "Bird-in-hand" }\end{array}$ & -12.8 & -0.6 & -6.1 & -3.7 & -3.4 & -0.8 \\
POIM & -12.8 & -1.4 & -7.1 & -1.4 & -2.3 & -1.4 \\
POIM-real criteria & -12.8 & -5.4 & -9.1 & -2.0 & -4.2 & -0.3 \\
Debt 30 & -12.8 & -8.9 & -10.8 & -0.3 & -5.4 & 0.3 \\
Unchanged & -12.8 & -9.9 & -10.8 & -9.9 & -10.1 & -9.9 \\
& & & & & & \\
Net financial wealth & & & & & & \\
"Bird-in-hand" & -4.0 & 13.8 & 2.1 & 81.6 & 58.0 & -0.1 \\
POIM & -4.0 & 7.8 & -0.6 & 131.1 & 68.9 & 144.8 \\
POIM-real criteria & -4.0 & -3.6 & -5.0 & 35.1 & 15.5 & 8.0 \\
Debt 30 & -4.0 & -13.6 & -8.6 & -30.0 & -28.9 & -30.0 \\
Unchanged & -4.0 & -13.4 & -7.8 & -237.9 & -94.5 & -1226.7 \\
\hline
\end{tabular}

Source: Russian authorities; and IMF staff estimations. 
Figure 1. Russian Federation: General Government Balances and Wealth, 2009-75 1/ (Percent of GDP)
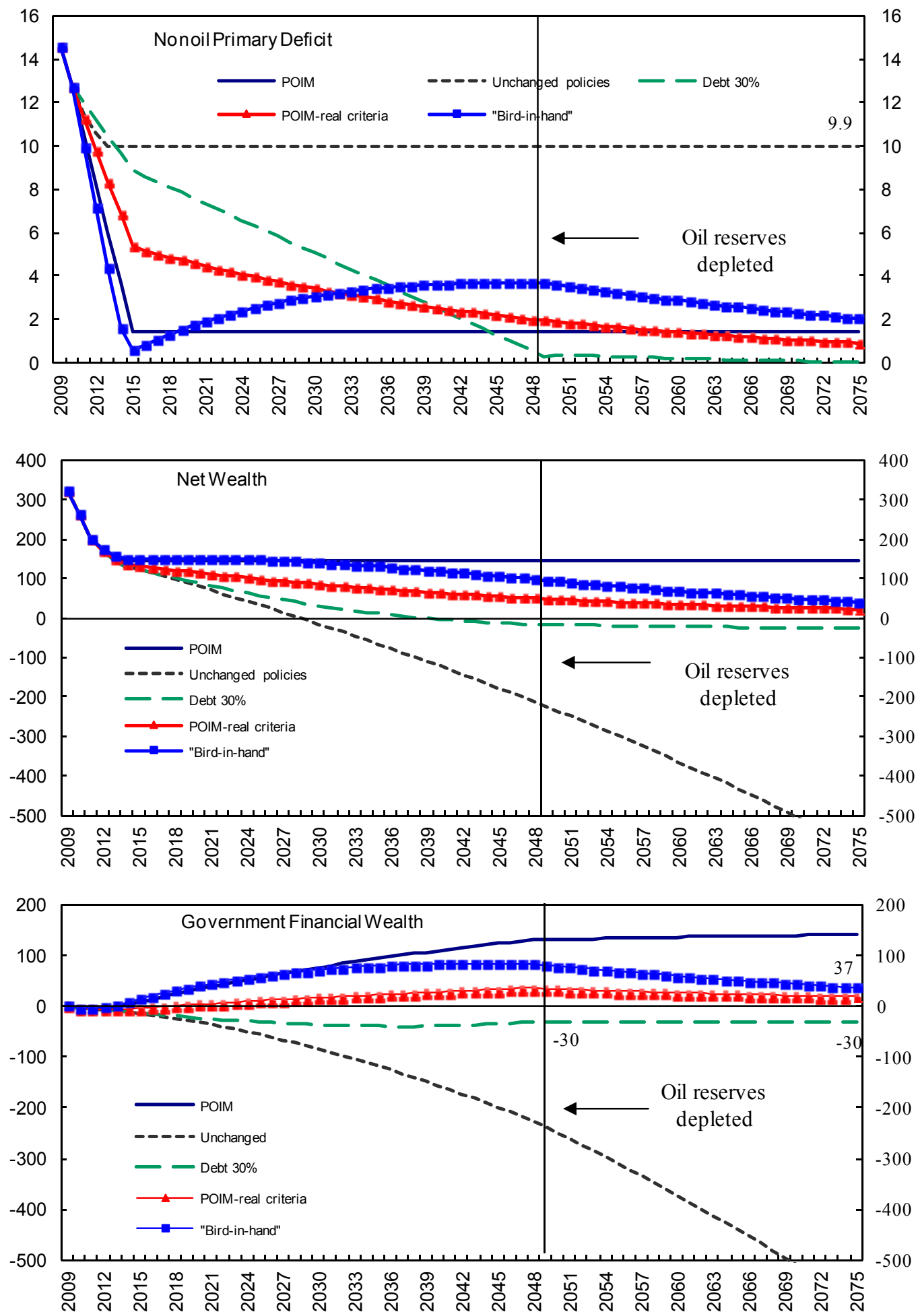

Source: IMF staff calculations.

1/ Simulation sare based on the July 2011 WEO oil prices; the "Unchanged policies" scenario assumes that the general government non-oil d eficit stabilizes at its 2013 level, implied by the medium-term bud get; "Debt $30 \%$ " scenario assumed that public debt is stabilized at 30 percent, once oil reserves are depleted; POIM-real criteria stabilizes government consumption in real terms; "bird-in-hand" rule sets the nonoil d eficit equal to a 4 percent real return on financial wealth. 


\section{References}

Barnett, Steven and Rolando Ossowski (2002) "Operational Aspects of Fiscal Policy in OilProducing Countries”, IMF WP 02/177.

Caracillo, Stéphane, Leigh, Daniel, and Mauricio Villafuerte (2007) “Catch-Up Growth, Habits, Oil Depletion, and Fiscal Policy: Lessons from the Republic of Congo, IMF WP 07/80.

Dabán, Teresa (2011), “Strengthening Chile’s Rules-Based Fiscal Framework”, IMF WP $11 / 17$.

Debrun, Xavier, David Hauner, and Manmohan Kumar (2009), "Independent Fiscal Agencies", Journal of Economic Surveys 23: 44-81.

Gurvich, Evsey (2010), “The Reform of 2010: Have the Long-Range Problems of the Pension System Been Solved?", Zhurnal Novoy ekonomicheskoy assotsiatsii, No. 6, 2010.

Hauner, David (2008), "Macroeconomic Effects of Pension Reform in Russia", IMF WP $08 / 201$.

Hofman, David, Julie Kozack, and Daria Zakharova (2012, forthcoming), "Russia: Rising and Falling With the Price of Oil" in How Emerging Europe Came Through the Global Crisis-An Inside Account by IMF staff, edited by Bas Bakker and Christoph Klingen, IMF.

International Monetary Fund (2003), "Sustainability Assessments-Review of Application and Methodological Refinements”, IMF Policy Paper, June 2003.

_ (2007a), "Norway: 2007 Article IV Consultation-Staff Report," IMF Country Report No. 07/196.

- (2007b), "Republic of Azerbaijan: 2007 Article IV Consultation-Staff Report," IMF Country Report No. 07/191.

(2007c), “Republic of Congo: Selected Issues,” IMF Country Report No. 07/206.

- (2009a), "Fiscal Rules-Anchoring Expectations for Sustainable Public Finances", IMF Policy Paper, December 2009.

(2009b), "Fiscal Implications of the Global Economic and Financial Crisis", IMF Occasional Paper No. 269. 
- (2011a), "Nigeria: 2010 Article IV Consultation-Staff Report," IMF Country Report No. 11/57.

- (2011b), “Russian Federation: 2011 Article IV Consultation-Staff Report,” IMF Country Report No. 11/294.

Kazakevitch, Peter and Alexandra Trishkina (2010), "The Russian Federation: Challenges for a Rainy Day" in Economics of Sovereign Wealth Funds: Issues for Policymakers, edited by Udaibir Das, Adnan Mazerei, and Han van der Hoorn, IMF.

Lienert, Ian (2010), “Should Advanced Countries Adopt a Fiscal Responsibility Law?”, IMF WP 10/254.

Medas, Paulo and Daria Zakharova (2009), “A Primer on Fiscal Analysis in Oil-Producing Countries", IMF WP/09/56.

OECD (2010), “OECD Economic Surveys: Norway”.

Ossowski, Rolando, Mauricio Villafuerte, and Paulo Medas (2008), "Managing the Oil Revenue Boom: The Role of Fiscal Institutions”, IMF Occasional Paper No. 260.

Sachs, Jeffrey (2007), "How to Handle the Macroeconomics of Oil Wealth?" in Escaping the Resource Curse, edited by George Soros, Columbia University Press, New York.

World Bank (2010), "Long-Term Fiscal Risks and Sustainability in an Oil-Rich Country: The Case of Russia”, WB Policy Research Working Paper 5240. 